\title{
PENGARUH MANAJEMEN MODAL KERJA TERHADAP PROFITABILITAS (STUDI PADA PERUSAHAAN PUPUK NEGARA TAHUN 2016-2020)
}

\author{
M. Yusuf Kurniawan' ${ }^{1}$, Fitria Ariyani ${ }^{2}$ \\ 르usufkurniawan@unigamalang.ac.id, ${ }^{2}$ fitriaariyani@unigamalang.ac.id \\ ${ }^{1,2}$ Universitas Gajayana
}

\begin{abstract}
ABSTRAK
Manajemen modal kerja berperan penting dalam mengukur keberhasilan perusahaan dalam meningkatkan laba. Pada era informasi saat ini, perusahaan perlu untuk mengelola modal kerja dengan efektif dan efisien. Tujuan penelitian ini adalah mengetahui dan menganalisis pengaruh manajemen modal kerja terhadap profitabilitas perusahaan. Penelitian ini menjelaskan pengaruh periode piutang, periode persediaan, dan periode hutang terhadap Return on Asset (ROA) perusahaan. Penelitian ini menggunakan metode deskriptif kuantitatif yang dilakukan pada perusahaan manufaktur penghasil pupuk yang terdaftar di bursa efek Indonesia sejak periode 2016 hingga 2020. Metode analisis data yang digunakan adalah analisis regresi linier berganda. Analisis yang meliputi periode piutang, periode persediaan, dan periode hutang dengan menggunakan data yang dikumpulkan dari laporan keuangan tahunan perusahaan, hasil penelitian menunjukan bahwa secara parsial pengaruh periode piutang dan periode persediaan berpengaruh positif signifikan terhadap profitabilitas, dimana hal ini berarti jika periode piutang dan periode persediaan bertambah lama maka profitabilitas akan meningkat. Oleh karena itu, pihak manajemen perusahaan dapat menciptakan nilai positif untuk perusahaan dengan memperlama periode piutang dan periode persediaan ke tingkat semaksimal mungkin. Pengaruh negatif signifikan terjadi pada periode hutang terhadap profitabilitas. Hal ini berarti jika periode hutang bertambah panjang maka profitabilitas perusahaan akan menurun. Oleh karena itu, pihak manajemen perusahaan dapat menciptakan nilai positif untuk perusahaan dengan mempersingkat periode hutang ke tingkat seminimum mungkin.

Kata Kunci: Manajemen Modal Kerja, Profitabilitas, Periode Piutang,

Periode Persediaan, Periode Hutang
\end{abstract}

\section{ABSTRACT}

Working capital management plays an important role in measuring the company's success in increasing profits. In the current information age, companies need to manage working capital effectively and efficiently. The purpose of this study was to determine and analyze the effect of working capital management on company profitability. This study explains the effect of the receivable period, inventory period, and debt period on the company's Return on Assets (ROA). This study uses a quantitative descriptive method carried out on fertilizer-producing manufacturing companies listed on the Indonesian stock exchange from 2016 to 2020. The data analysis method used 
Kurniawan, Pengaruh Manajemen Modal Kerja

is multiple linear regression analysis. The analysis includes the accounts receivable period, inventory period, and payable period using data collected from the company's annual financial statements, the results of the study show that partially the influence of the accounts receivable period and the inventory period has a significant positive effect on profitability, which means that the receivable period and the inventory period have a significant positive effect on profitability. As inventory increases, profitability will increase. Therefore, the company's management can create positive value for the company by extending the accounts receivable period and the inventory period to the maximum possible level. A significant negative effect occurs in the debt period on profitability. This means that if the debt period is longer, the company's profitability will decrease. Therefore, the company's management can create positive value for the company by shortening the debt period to a minimum level.

Keywords: Working Capital Management, Profitability, Accounts Receivable Period, Inventory Period, Payable Period

\section{PENDAHULUAN}

Suatu perusahaan dituntut untuk menjaga keberlangsungan usahanya, salah satu cara perusahaan untuk tetap eksis dan mampu bersaing dengan kompetitor adalah dengan meningkatkan profitabilitas perusahaan tiap tahun. Perusahaan pupuk negara dapat mengimplementasikan cara tersebut apabila ingin tetap eksis dan mampu bersaing dengan kompetitornya, namun dari data historis 5 tahun (2016-2020), salah satu permasalahan yang dihadapi oleh perusahaan pupuk negara untuk dapat menjaga keberlangsungan usahanya adalah fluktuatifnya profitabilitas perusahaan dan cenderung mengalami penurunan tiap tahunnya. Profitabilitas pupuk negara yang diukur dengan Return on Asset mengalami penurunan yang cukup signifikan, yaitu sebesar $13,87 \%$ per tahun. Salah satu faktor penyebab menurunnya profitabilitas perusahaan pupuk negara adalah manajemen modal kerja yang kurang efisien. (Annual Report Perusahaan Pupuk Negara 2016-2020).

Salah satu indikator kurang efisiennya penerapan manajemen modal kerja terlihat pada banyaknya modal kerja yang tertahan pada aset lancar terutama pada pos piutang usaha, semakin lama waktu yang diperlukan untuk menagih piutang maka terdapat opportunity cost yang tinggi sehingga akan berdampak pada penurunan profitabilitas perusahaan (Enqvist, Graham dan Nikkinen 2012). Banyaknya dana perusahaan yang mengendap pada piutang tersebut ditentukan oleh volume penjualan kredit, syarat pembayaran kredit, ketentuan pembatasan kredit, kebijaksanaan pengumpulan piutang, dan kebiasaan membayar dari para langganan (Riyanto, 2011). Semakin longgar syarat pembayaran yang diberikan, maka jumlah modal kerja yang tertahan dipiutang akan semakin meningkat.

Permasalahan tingginya piutang usaha tersebut juga dihadapi oleh 5 perusahan pupuk negara, dari data historis 5 tahun (2016-2020) rata-rata prosentase piutang usaha perusahaan pupuk negara dibandingkan dengan aset lancarnya sebesar 39,28\% atau bisa dikatakan hampir $40 \%$ modal kerja perusahaan pupuk negara banyak mengendap di piutang. Komposisi piutang usaha tersebut di dominasi oleh piutang pupuk subsidi oleh pemerintah yaitu sebesar 59,69\% dari total piutang usaha (Annual Report Perusahaan Pupuk Negara 2016-2020). Tingginya piutang subsidi tersebut, akibat anggaran subsidi pupuk yang diputus di dalam APBN tidak sesuai dengan jumlah kuantum pupuk yang sudah disalurkan ke petani. Saldo utang subsidi pemerintah kepada produsen pupuk 
negara per 31 Desember 2016 sesuai Laporan Keuangan Pemerintah Pusat Tahun 2016 (audited) sebesar Rp 12,107 triliyun, disisi lain total piutang subsidi per 31 Desember 2016 dari kelima produsen pupuk negara sebesar Rp 19,487 triliyun, sehingga ada selisih sebesar Rp 7,380 triliyun yang masih akan dianggarkan oleh pemerintah di tahun selanjutnya.

Tingginya piutang usaha tersebut berpotensi menimbulkan risiko menurunnya profitabilitas dan keberlangsungan perusahaan jika pembayaran piutang usaha tersebut kurang lancar bahkan sampai tidak tertagih (Ullah, et al 2007). Tingginya modal kerja yang mengendap pada piutang usaha, akan berdampak pada likuiditas perusahaan untuk memenuhi kewajiban jangka pendeknya. Keterbatasan modal kerja tersebut mengharuskan perusahaan untuk menarik kredit modal kerja pada perbankan yang bedampak pada naiknya biaya bunga dan berpengaruh pada penurunan profitabilitas perusahaan. Adanya isu pencabutan/pengalihan subsidi pupuk oleh Menteri Pertanian sejak tahun 2014 juga menjadi isu strategis yang harus diselesaikan oleh produsen pupuk negara jika ingin keberlangsungan bisnisnya tetap berjalan, mengingat sebagian besar modal kerja didominasi oleh piutang subsidi pemerintah. Pencabutan atau pengalihan subsidi pupuk tersebut karena dianggap tidak tepat sasaran dan sebaiknya subisidi tersebut dapat diberikan untuk kompensasi petani, perbaikan irigasi dan jaminan harga (merdeka.com).

Modal kerja perusahaan pupuk negara juga didominasi oleh persediaan, dari data historis 5 tahun terakhir (2016-2020) rata-rata prosentase persediaan perusahaan pupuk negara dibandingkan dengan aset lancarnya sebesar 28,04\%. Tingginya persediaan tersebut karena tingginya persediaan bahan baku dan barang jadi terutama pupuk non subsidi (Annual Report Perusahaan Pupuk Negara 2016 - 2020). Tingginya stok barang jadi pupuk non subsidi ini karena produsen pupuk dari China yang mulai ekspansi ke Indonesia dengan membangun industri urea berbasis batu bara dengan teknologi gasifikasi, dan produsen pupuk dari Amerika Serikat memanfaatkan teknologi sel gas yang jauh lebih murah harga bahan bakunya, hanya 2,8 dollar AS per juta Metrik British Termal Unit (MMBTU) (kompas.com), tentu hal ini berdampak pada harga pupuk nasional kalah bersaing dalam pasar bebas. Harga pokok produksi perusahaan pupuk negara yang tinggi berdampak pada harga jualnya yang lebih tinggi dibandingkan dengan harga pokok produksi perusahaan pupuk dari China. Tingginya harga jual tersebut berdampak pada rendahnya penyerapan pupuk non subsidi yang mengakibatkan tingginya persediaan perushaaan pupuk negara.

Besaran nilai persediaan berbanding lurus dengan biaya penyimpanan dan risiko kerusakan barang jadi, disisi lain tertahannya modal kerja pada persediaan akan mengurangi profitabilitas perusahaan (Karaduman, et al., 2010). Tingginya modal kerja yang tertanam di piutang dan persediaan berdampak pada terlambatnya pemenuhan atau pembayaran kewajiban lancar perusahaan pupuk negara. Menunda pembayaran kepada pemasok memungkinkan perusahaan untuk menilai kualitas produk yang dibeli, dan dapat menjadi sumber pembiayaan yang fleksibel dan murah bagi perusahaan, disisi lain, keterlambatan pembayaran faktur dapat menambah biaya pembelian jika pemasok memberikan diskon untuk pembayaran awal serta kepercayaan pemasok berisiko menurun (Deloof, 2003).

Berdasarkan fenomena di atas, peneliti ingin mengetahui hubungan manajemen modal kerja dengan profitablitas perusahaan. Dari fenomena tersebut dapat diindikasikan bahwa modal kerja memiliki peran penting bagi profitabilitas perusahaan. Pada kasus perusahaan pupuk negara modal kerja yang didominasi piutang usaha dan persediaan berdampak pada meningkatnya penarikan KMK, tingginya biaya penyimpanan serta ketepatan waktu pemenuhan kewajiban lancar yang berpengaruh pada tingkat 
Kurniawan, Pengaruh Manajemen Modal Kerja

profitabilitas perusahaan. Modal kerja adalah investasi total perusahaan pada aktiva lancar atau aktiva yang diharapkan dapat dikonversi menjadi kas dalam waktu satu tahun atau kurang dari satu tahun (Keown et al, 2010), sedangkan manajemen modal kerja adalah kegiatan yang melibatkan perencanaan dan pengendalian aktiva lancar dan kewajiban lancar dengan cara menghilangkan risiko ketidakmampuan untuk memenuhi kewajiban jangka pendek dan menghindari investasi yang berlebihan pada aset lancar perusahaan (Eljeli, 2004). Untuk dapat menentukan jumlah modal kerja yang efisien, terlebih dahulu diukur dari elemen-elemen modal kerja. Menurut Esra dan Apriweni (2002), dalam pengelolaan modal kerja perlu diperhatikan tiga elemen utama modal kerja, yaitu kas, piutang dan persediaan.

Profitabilitas adalah hubungan antara pendapatan dan biaya yang dihasilkan dengan menggunakan aset perusahaan (Gitman, 2009). Melihat permasalahan yang dihadapi perusahaan pupuk negara adalah kurang maksimalnya penggunaan aset untuk meningkatkan profitabiltas perusahaan, untuk itu dalam penelitian ini rasio profitabilitas yang digunakan adalah Return on Asset (ROA). Menurut Tandelilin (2001) Return on Assets menggambarkan sejauh mana kemampuan aset-aset yang dimiliki perusahaan bisa menghasilkan laba. Return on Assets menunjukkan seberapa banyak laba bersih yang bisa diperoleh dari seluruh kekayaan yang dimiliki perusahaan, karena itu dipergunakan angka laba setelah pajak dan (rata-rata) kekayaan perusahaan.

Salah satu indikator pengukuran efektifitas modal kerja adalah Cash Conversion Cycle. Menurut Keown (2010) Cash Conversion Cycle (CCC) merupakan penjumlahan sederhana dari jumlah hari piutang (Days of Sales Outstanding) dan jumlah hari penjualan persediaan (Days of Sales in Inventory) dikurangi jumlah hari pembayaran yang belum diselesaikan (Days of Payable Outstanding), atau dapat dikatakan semakin pendek siklus konversi kas maka efektifitas penggunaan modal kerja semakin baik, karena dapat menghemat biaya yang berdampak pada meningkatnya profitabilitas perusahaan. Berdasarkan penelitian Deloof (2003), Tu dan Nguyen (2012) dan Napompech (2012) ditemukan fakta bahwa Cash Conversion Cycle memiliki hubungan negatif dengan profitabilitas yang diukur Gross Operating Profit. Hal ini sependapat dengan penelitian Karaduman, et al (2010), Quayyum (2011) Attari dan Raza (2012) yang mengemukakan bahwa Cash Conversion Cycle memiliki hubungan negatif dengan profitabilitas yang diukur dengan Return on Asset.

Dari beberapa penelitian tersebut dapat disimpulkan bahwa dengan mempercepat atau memperpendek Cash Conversion Cycle, maka akan dapat meningkatkan profitabilitas perusahaan. Disisi lain penelitian yang dilakukan Ullah, et al (2007) menemukan fakta bahwa Cash Conversion Cycle memiliki hubungan positif signifikan dengan profitabilitas perusahaan yang diukur dengan Return On Equity, hal ini membuktikan bahwa peningkatan kas, persediaan dan penjualan kredit akan menyebabkan peningkatan profitabilitas perusahaan. Siklus konversi kas sendiri dapat di breakdown menjadi tiga komponen yaitu Days of Sales Outstanding, Days of Sales in Inventory, dan Days of Payable Outstanding. Mempercepat atau memperpendek Days of Sales Outstanding akan dapat meningkatkan profitabilitas, hal ini sesuai dengan penelitian Deloof (2013), Tu dan Nguyen (2012) dan Napompech (2012) bahwa dengan cara mengurangi jumlah hari penagihan piutang maka profitabilitas perusahaan yang diukur dengan Gross Operating Profit akan meningkat. Disisi lain penelitian Karaduman, et al (2010), Quayyum (2011) Attari dan Raza (2012) juga sependapat bahwa Days of Sales Outstanding memiliki pengaruh negatif terhadap profitabilitas yang diukur oleh Return on Asset. Akoto, et al (2013) juga menemukan hal yang sama bahwa Days of Sales Outstanding memiliki hubungan negatif signifikan dengan profitabilitas yang diukur dengan Return On Equity, akan tetapi penelitian yang dilakukan oleh Muscettola (2014) dan Ullah,et al (2007) bahwa Days of Sales Outstanding memiliki hubungan 
positif signifikan terhadap profitabilitas yang diukur dengan EBITDA/ Net Sales, hal ini menunjukan bahwa kebijakan penjualan kredit yang longgar akan dapat meningkatkan volume penjualan, sehingga profitabilitas perusahaan dapat meningkat.

Days of Sales in Inventory juga menjadi salah indikator penentu cepat atau lamanya Cash Conversion Cycle. Mempercepat atau memperpendek Days of Sales in Inventory juga akan dapat meningkatkan profitabilitas, hal ini sesuai dengan penelitian Deloof (2013), Tu dan Nguyen (2012), dan Napompech (2012) bahwa Days of Sales in Inventory memiliki hubungan negatif signifikan terhadap profitabilitas yang diukur dengan Gross Operating Profit. Karaduman, et al (2010), Attari dan Raza (2012) menemukan hal yang sama bahwa Days of Sales in Inventory juga memiliki hubungan negatif dengan profitabilitas yang diukur dengan Return on Asset. Dari beberapa penelitian tersebut dapat disimpulkan bahwa dengan mempercepat Days of Sales in Inventory akan menghemat biaya penyimpanan bahan baku, work in process dan meminimalisir kerusakan barang jadi, sehingga dapat meningkatkan profitabilitas perusahaan. Disisi lain penelitian yang dilakukan Ullah, et al (2007) menemukan fakta bahwa Days of Sales in Inventory memiliki hubungan positif signifikan dengan profitabilitas perusahaan yang diukur dengan Return On Equity, hal ini membuktikan bahwa menyimpan persediaan dapat meningkatkan profitabilitas dampak dari efisiensi biaya pemesanan yang tidak berulang-ulang.

Days of Payable Outstanding dipengaruhi oleh cepat atau lamanya Days of Sales Outstanding dan Days of Sales in Inventory. Apabila semakin cepat penarikan piutang perusahaan dan tidak banyak modal kerja yang tertahan di persediaan maka pemenuhan/pembayaran kewajiban lancar terutama utang usaha akan tepat waktu. Ketepatan waktu pembayaran utang usaha tersebut dapat mempengaruhi profitabilitas perusahaan, hal ini sesuai fakta yang ditemukan dalam penelitian Deloof (2003), Tu dan Nguyen (2012) yang menyatakan adanya hubungan negatif signifikan antara Days of Payable Outstanding dengan profitabilitas yang diukur dengan Gross Operating Profit. Penelitian Karaduman, et al (2010) dan Attari dan Raza (2012) juga sependapat bahwa Days of Payable Outstanding memiliki hubungan negatif dengan profitabilitas yang diukur dengan Return on Assets. Siklus konversi kas dapat diperpendek dengan cara memperpanjang umur pembayaran utang, namun perlu dicatat, manajemen diharapkan dapat memperlambat pembayaran utang tanpa merusak reputasi dan kredibilitasnya. Dalam arti pelambatan pembayaran utang hanya boleh dilakukan sampai batas maksimum pembayaran utang yang telah diijinkan oleh kreditornya. Dengan memperlambat pembayaran utang maka perusahaan dapat memanfaatkan dana yang ada untuk keperluan lainnya ataupun dapat disimpan dalam investasi jangka pendek yang bersifat likuid sehingga akan mendatangkan pemasukan bagi perusahaan. Hal ini sesuai dengan hasil penelitian Quayyum (2011) dan Ullah, et al (2007) bahwa menunda pembayaran pada supplier dapat meningkatkan profitabilitas perusahaan.

\section{TINJAUAN PUSTAKA}

Profitabilitas adalah hubungan antara pendapatan dan biaya yang dihasilkan dengan menggunakan aset perusahaan (Gitman, 2009). Melihat permasalahan yang dihadapi perusahaan pupuk negara adalah kurang maksimalnya penggunaan aset untuk meningkatkan profitabiltas perusahaan, untuk itu dalam penelitian ini rasio profitabilitas yang digunakan adalah Return on Asset (ROA). Menurut Tandelilin (2001) Return on Assets menggambarkan sejauh mana kemampuan aset-aset yang dimiliki perusahaan bisa menghasilkan laba. Return on Assets menunjukkan seberapa banyak laba bersih yang bisa 
diperoleh dari seluruh kekayaan yang dimiliki perusahaan, karena itu dipergunakan angka laba setelah pajak dan (rata-rata) kekayaan perusahaan.

Salah satu indikator pengukuran efektifitas modal kerja adalah Cash Conversion Cycle. Menurut Keown (2010) Cash Conversion Cycle (CCC) merupakan penjumlahan sederhana dari jumlah hari piutang (Days of Sales Outstanding) dan jumlah hari penjualan persediaan (Days of Sales in Inventory) dikurangi jumlah hari pembayaran yang belum diselesaikan (Days of Payable Outstanding), atau dapat dikatakan semakin pendek siklus konversi kas maka efektifitas penggunaan modal kerja semakin baik, karena dapat menghemat biaya yang berdampak pada meningkatnya profitabilitas perusahaan. Berdasarkan penelitian Deloof (2003), Tu dan Nguyen (2012) dan Napompech (2012) ditemukan fakta bahwa Cash Conversion Cycle memiliki hubungan negatif dengan profitabilitas yang diukur Gross Operating Profit. Hal ini sependapat dengan penelitian Karaduman, et al (2010), Quayyum (2011) Attari dan Raza (2012) yang mengemukakan bahwa Cash Conversion Cycle memiliki hubungan negatif dengan profitabilitas yang diukur dengan Return on Asset.

Dari beberapa penelitian tersebut dapat disimpulkan bahwa dengan mempercepat atau memperpendek Cash Conversion Cycle, maka akan dapat meningkatkan profitabilitas perusahaan. Disisi lain penelitian yang dilakukan Ullah, et al (2007) menemukan fakta bahwa Cash Conversion Cycle memiliki hubungan positif signifikan dengan profitabilitas perusahaan yang diukur dengan Return On Equity, hal ini membuktikan bahwa peningkatan kas, persediaan dan penjualan kredit akan menyebabkan peningkatan profitabilitas perusahaan. Siklus konversi kas sendiri dapat di breakdown menjadi tiga komponen yaitu Days of Sales Outstanding, Days of Sales in Inventory, dan Days of Payable Outstanding. Mempercepat atau memperpendek Days of Sales Outstanding akan dapat meningkatkan profitabilitas, hal ini sesuai dengan penelitian Deloof (2013), Tu dan Nguyen (2012) dan Napompech (2012) bahwa dengan cara mengurangi jumlah hari penagihan piutang maka profitabilitas perusahaan yang diukur dengan Gross Operating Profit akan meningkat. Disisi lain penelitian Karaduman, et al (2010), Quayyum (2011) Attari dan Raza (2012) juga sependapat bahwa Days of Sales Outstanding memiliki pengaruh negatif terhadap profitabilitas yang diukur oleh Return on Asset. Akoto, et al (2013) juga menemukan hal yang sama bahwa Days of Sales Outstanding memiliki hubungan negatif signifikan dengan profitabilitas yang diukur dengan Return On Equity, akan tetapi penelitian yang dilakukan oleh Muscettola (2014) dan Ullah,et al (2007) bahwa Days of Sales Outstanding memiliki hubungan positif signifikan terhadap profitabilitas yang diukur dengan EBITDA/ Net Sales, hal ini menunjukan bahwa kebijakan penjualan kredit yang longgar akan dapat meningkatkan volume penjualan, sehingga profitabilitas perusahaan dapat meningkat.

Days of Sales in Inventory juga menjadi salah indikator penentu cepat atau lamanya Cash Conversion Cycle. Mempercepat atau memperpendek Days of Sales in Inventory juga akan dapat meningkatkan profitabilitas, hal ini sesuai dengan penelitian Deloof (2013), Tu dan Nguyen (2012), dan Napompech (2012) bahwa Days of Sales in Inventory memiliki hubungan negatif signifikan terhadap profitabilitas yang diukur dengan Gross Operating Profit. Karaduman, et al (2010), Attari dan Raza (2012) menemukan hal yang sama bahwa Days of Sales in Inventory juga memiliki hubungan negatif dengan profitabilitas yang diukur dengan Return on Asset. Dari beberapa penelitian tersebut dapat disimpulkan bahwa dengan mempercepat Days of Sales in Inventory akan menghemat biaya penyimpanan bahan baku, work in process dan meminimalisir kerusakan barang jadi, sehingga dapat meningkatkan profitabilitas perusahaan. Disisi lain penelitian yang dilakukan Ullah, et al (2007) menemukan fakta bahwa Days of Sales in Inventory memiliki hubungan positif signifikan dengan profitabilitas perusahaan yang diukur dengan Return On Equity, hal ini membuktikan 
bahwa menyimpan persediaan dapat meningkatkan profitabilitas dampak dari efisiensi biaya pemesanan yang tidak berulang-ulang.

Days of Payable Outstanding dipengaruhi oleh cepat atau lamanya Days of Sales Outstanding dan Days of Sales in Inventory. Apabila semakin cepat penarikan piutang perusahaan dan tidak banyak modal kerja yang tertahan di persediaan maka pemenuhan/pembayaran kewajiban lancar terutama utang usaha akan tepat waktu. Ketepatan waktu pembayaran utang usaha tersebut dapat mempengaruhi profitabilitas perusahaan, hal ini sesuai fakta yang ditemukan dalam penelitian Deloof (2003), Tu dan Nguyen (2012) yang menyatakan adanya hubungan negatif signifikan antara Days of Payable Outstanding dengan profitabilitas yang diukur dengan Gross Operating Profit. Penelitian Karaduman, et al (2010) dan Attari dan Raza (2012) juga sependapat bahwa Days of Payable Outstanding memiliki hubungan negatif dengan profitabilitas yang diukur dengan Return on Assets. Siklus konversi kas dapat diperpendek dengan cara memperpanjang umur pembayaran utang, namun perlu dicatat, manajemen diharapkan dapat memperlambat pembayaran utang tanpa merusak reputasi dan kredibilitasnya. Dalam arti pelambatan pembayaran utang hanya boleh dilakukan sampai batas maksimum pembayaran utang yang telah diijinkan oleh kreditornya. Dengan memperlambat pembayaran utang maka perusahaan dapat memanfaatkan dana yang ada untuk keperluan lainnya ataupun dapat disimpan dalam investasi jangka pendek yang bersifat likuid sehingga akan mendatangkan pemasukan bagi perusahaan. Hal ini sesuai dengan hasil penelitian Quayyum (2011) dan Ullah, et al (2007) bahwa menunda pembayaran pada supplier dapat meningkatkan profitabilitas perusahaan.

Rumusan Masalah:

1. Apakah Days of Sales Outstanding berpengaruh negatif signifikan terhadap Return on Asset pada perusahaan Pupuk Negara?

2. Apakah Days of Sales in Inventory berpengaruh negatif signifikan terhadap Return on Asset pada perusahaan Pupuk Negara?

3. Apakah Days of Payable Outstanding berpengaruh negatif signifikan terhadap Return on Asset pada perusahaan Pupuk Negara?

\section{METODE PENELITIAN}

Penelitian ini mempergunakan suatu paradigma positivisme dengan pendekatan kuantitatif. Pendekatan kuantitatif ini dilakukan dalam penelitian inferensial (dalam tujuan pengujian hipotesis) dan untuk memperoleh suatu hasil kesimpulan pada suatu probabilitas kesalahan pada penolakan hipotesis nihil. Melalui penggunaan metode penelitian kuantitatif tersebut selanjutnya dapat diperoleh tingkat signifikasi hubungan antar variabel yang berada pada suatu model penelitian. Berdasarkan rumusan permasalahan, tujuan penelitian, dan hipotesis yang diajukan, maka penelitian ini adalah penelitian explanatory.

Populasi dalam penelitian ini adalah perusahaan pupuk negara. Penentuan sampel menggunakan metode sensus. Menurut Sugiyono (2013) metode sensus adalah teknik penentuan sampel dimana penentuan jumlah sampel sama dengan semua anggota populasi. Dalam penelitian ini karena jumlah populasinya sedikit (terbatas) sehingga jumlah sampel sama dengan jumlah populasinya. Data yang dibutuhkan untuk penelitian ini adalah laporan keuangan tahunan perusahaan yang diperoleh dari Bursa Efek Indonesia (BEI).

Teknik analisis data yang digunakan dalam penelitian ini yaitu analisis statistik dengan menggunakan regresi berganda yang dilakukan dengan bantuan software SPSS. Untuk mencegah terjadinya masalah-masalah dalam penggunaan analisis regresi maka 
terlebih dahulu dilakukan Uji Asumsi Klasik yang terdiri dari uji normalitas, uji multikolinieritas, uji autokorelasi, dan uji heteroskedastisitas. Model Regresi Berganda menurut Mudrajat Kuncoro (2009:236), analisis regresi berganda tersebut dapat diformulasikan sebagai berikut:

Keterangan:

$$
\mathrm{Y}=\mathrm{b} 0+\mathrm{b} 1 \mathrm{X} 1+\mathrm{b} 2 \mathrm{X} 2+\ldots .+\mathrm{bnXn}+\mathrm{e}
$$

$\mathrm{Y} \quad$ : Return on Asset (ROA)

b0 : Konstanta

b1 ... b3: Koefisien arah regresi

X1 : Days of Sales Outstanding (DSO)

$\mathrm{X} 2 \quad$ : Days of Sales in Inventory (DSI)

X3 : Days of Payable in Outstanding (DPO)

e : Kesalahan pengganggu (error)

Pada umumnya dalam melakukan pengujian hipotesis ada dua macam cara pengujian, yaitu Pengujian Hipotesis secara simultan (bersama-sama) dan Pengujian Hipotesis secara parsial (masing-masing). Namun dalam penelitian ini akan digunakan satu macam pengujian hipotesis saja yaitu Pengujian Hipotesis secara parsial (masingmasing) karena menurut Augusty (2014) pada penelitian yang ingin mencari pengaruh tidaklah perlu dilakukan pengujian secara simultan dengan alasan yaitu sudah pasti adanya pengaruh antara variabel independen dengan variabel dependen. Pengujian hipotesis secara parsial dilakukan dengan uji t:

H1: Diduga DSO berpengaruh signifikan terhadap ROA.

H2: Diduga DSI berpengaruh signifikan terhadap ROA.

H3: Diduga DPO berpengaruh signifikan terhadap ROA.

Kriteria dalam pengambilan keputusan hipotesis dilakukan dengan membandingkan nilai signifikansi dari masing-masing variabel, yaitu harus lebih kecil dari 0,05 / 5\% dengan ketentuan:

- Jika nilai signifikansi lebih kecil dari 5\%, maka H0 ditolak dan Ha diterima.

- Jika nilai signifikansi lebih besar dari 5\%, maka H0 diterima dan Ha ditolak.

Gambar 1 Kerangka Konseptual Penelitian

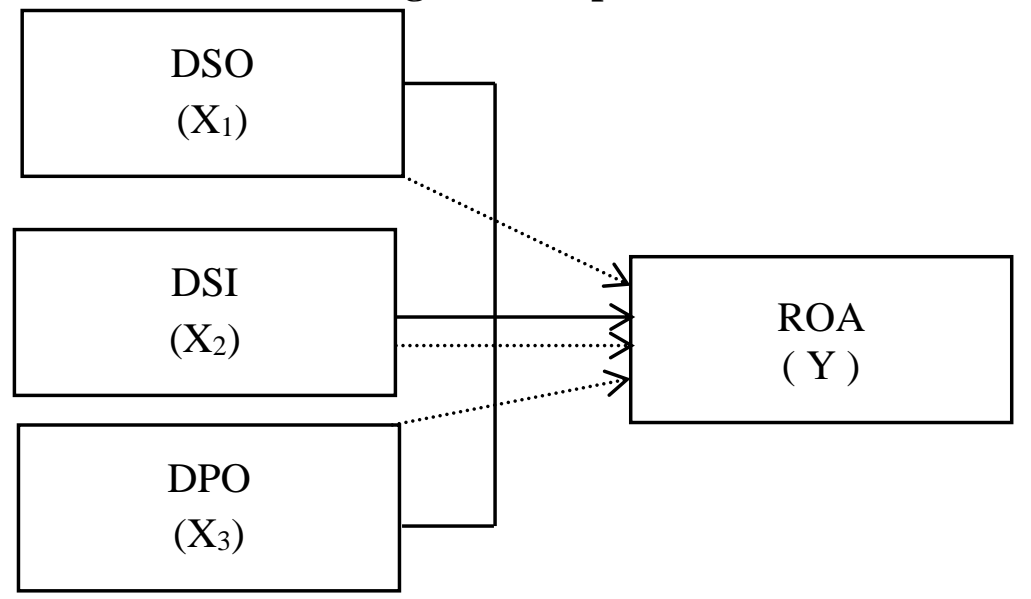

Sumber: berbagai pendapat dan publikasi 


\section{HASIL DAN PEMBAHASAN}

\section{Hasil Uji Asumsi Klasik}

1. Hasil Uji Normalitas

Berdasarkan hasil uji Kolmogrov - Smirnov menunjukkan bahwa signifikansi dari masing-masing variabel independen yang dilihat dari Asymp. Sig. (2-tailed) di atas 0,05. Sehingga dapat disimpulkan bahwa data masing-masing variabel independen yang digunakan untuk model regresi berdistribusi normal.

2. Hasil Uji Multikolinieritas

Berdasarkan hasil uji multikolinieritas menunjukkan bahwa masing-masing variabel independen mempunyai nilai VIF $\leq 10$ dan nilai tolerance lebih tinggi dari 0,1 . Sehingga diperoleh kesimpulan bahwa semua variabel independen bebas dari masalah multikolinieritas.

3. Hasil Uji Autokorelasi

Berdasarkan hasil uji autokorelasi dengan Durbin Watson menunjukkan bahwa nilai DW sebesar 1,271. Nilai $\mathrm{dL}=1,246$ dan nilai $\mathrm{dU}=1,875$. Karena nilai DW model regresi 1,271 berada diantara $\mathrm{dL}=1,246$ dan $4-\mathrm{dU}=2,125$, yaitu daerah tidak ada autokorelasi maka dapat disimpulkan tidak terjadi autokorelasi pada model regresi.

4. Hasil Uji Heteroskedastisitas

Berdasarkan uji heteroskedastisitas dengan Scatterplot menunjukkan bahwa titik-titik menyebar di atas dan di bawah angka 0 pada sumbu Y serta tidak membentuk suatu pola tertentu. Maka dapat disimpulkan bahwa dalam model regresi tidak terjadi heteroskedastisitas.

\section{Hasil Analisis Regresi Berganda}

Tabel 1 Tabel Analisis Regresi Linier Berganda

\begin{tabular}{|c|c|c|c|c|c|c|}
\hline \multirow{2}{*}{ Model } & \multicolumn{2}{|c|}{$\begin{array}{c}\text { Unstandardized } \\
\text { Coefficients }\end{array}$} & \multirow{2}{*}{$\begin{array}{c}\begin{array}{c}\text { Standardized } \\
\text { Coefficients }\end{array} \\
\text { Beta }\end{array}$} & \multirow[t]{2}{*}{$\mathbf{t}$} & \multirow[t]{2}{*}{ Sig. } & \multirow[t]{2}{*}{ Keterangan } \\
\hline & B & Std. Error & & & & \\
\hline & .360 & .091 & & .000 & 1.000 & \\
\hline DSO & .214 & .143 & .214 & 2.497 & .014 & Signifikan \\
\hline 1 DSI & -.228 & .098 & -.228 & 2.331 & .025 & Signifikan \\
\hline DPO & -.409 & .166 & -.409 & $\begin{array}{c}- \\
2.466\end{array}$ & .018 & Signifikan \\
\hline
\end{tabular}

Sumber: data diolah, 2021

Dari hasil regresi linier berganda, didapatkan model yang diinterpretasikan sebagai berikut:

Keterangan:

$$
\mathrm{Y}=0,360+0,214 \mathrm{X} 1-0,228 \mathrm{X} 2-0,409 \mathrm{X} 3
$$

- B0 atau nilai konstanta, dimana konstanta menunjukkan bila tidak ada variabel DSO, DSI, dan DPO maka nilai Return on Asset (ROA) sebesar 0,360 satuan.

- B1 atau nilai parameter dari Days of Sales Outstanding (DSO) menunjukkan bahwa setiap 1 satuan DSO meningkat maka Return on Asset (ROA) akan meningkat sebesar 0,214 satuan dengan asumsi bahwa variabel yang lainnya sama dengan nol. Nilai signifikansi DSO sebesar 0,014, sehingga dapat disimpulkan bahwa Days of Sales 
Outstanding berpengaruh signifikan pada level 5\% dengan arah positif terhadap ROA perusahaan pupuk.

- B2 atau nilai parameter dari Days of Sales in Inventory (DSI) menunjukkan bahwa setiap 1 satuan DSI meningkat maka Return on Asset (ROA) akan menurun sebesar 0,228 satuan dengan asumsi bahwa variabel yang lainnya sama dengan nol. Nilai signifikansi DSI sebesar 0,025, sehingga dapat disimpulkan bahwa Days of Sales in Inventory berpengaruh signifikan pada level 5\% dengan arah negatif terhadap ROA perusahaan pupuk.

- B3 atau nilai parameter dari Days of Payable in Outstanding (DPO) menunjukkan bahwa setiap 1 satuan DPO meningkat maka Return on Asset (ROA) akan menurun sebesar 0,409 satuan dengan asumsi bahwa variabel yang lainnya sama dengan nol. Nilai signifikansi DPO sebesar 0,018, sehingga dapat disimpulkan bahwa Days of Payable in Outstanding berpengaruh signifikan pada level 5\% dengan arah negatif terhadap ROA perusahaan pupuk.

\section{Hasil Uji Hipotesis}

Berdasarkan hasil analisis uji t, dapat diketahui pengaruh variabel Days of Sales Outstanding (DSO), Days of Sales in Inventory (DSI), dan Days of Payable in Outstanding (DPO) terhadap Return on Asset (ROA), sebagai berikut:

- Uji hipotesis 1, variabel Days of Sales Outstanding (DSO) mempunyai nilai signifikan 0,014 lebih kecil dari taraf signifikansi yaitu 0,05. Oleh karena itu H0 ditolak dan Ha diterima, artinya H1 yang menyatakan Days of Sales Outstanding berpengaruh signifikan terhadap Return on Asset, diterima.

- Uji hipotesis 2, variabel Days of Sales in Inventory (DSI) mempunyai nilai signifikan 0,025 lebih kecil dari taraf signifikansi yaitu 0,05. Oleh karena itu H0 ditolak dan Ha diterima, artinya $\mathrm{H} 2$ yang menyatakan Days of Sales in Inventory berpengaruh signifikan terhadap Return on Asset, diterima.

- Uji hipotesis 3, variabel Days of Payable in Outstanding (DPO) mempunyai nilai signifikan 0,018 lebih kecil dari taraf signifikansi yaitu 0,05. Oleh karena itu H0 ditolak dan Ha diterima, artinya H3 yang menyatakan Days of Payable in Outstanding berpengaruh signifikan terhadap Return on Asset, diterima.

\section{Pembahasan Hasil}

\section{Pengaruh Days of Sales Outstanding terhadap Return on Asset}

Days of Sales Outstanding menurut Brigham dan Houston (2001) adalah periode penagihan piutang rata-rata. Days Sales Outstanding, digunakan untuk menaksir piutang usaha, dan dihitung dengan membagi piutang usaha dengan rata-rata penjualan harian untuk menentukan jumlah hari penjualan dalam piutang usaha. Rasio ini mengukur periode waktu perusahaan mendapatkan kas setelah menjual barang atau jasa. Jika nilai Days of Sales Outstanding rendah, hal tersebut mengindikasikan perusahaan memerlukan waktu yang singkat dalam menagih piutang usahanya. Dalam aktivitas operasional pada umumnya perusahaan membutuhkan kas untuk mendanai biaya operasional, oleh karena itu periode penagihan piutang yang singkat sangat penting bagi kelancaran cash flow perusahaan.

Jika manajemen berhasil mempersingkat waktu yang dibutuhkan dalam menagih piutang usahanya, maka manajemen memiliki peluang untuk menggunakan kas tersebut pada kesempatan (investasi) lain yang menguntungkan. Akan tetapi di sisi lain upaya ini mengindikasikan bahawa perusahaan melakukan upaya yang agresif untuk pengumpulan piutangnya yang berdampak pada risiko kehilangan pelanggan di kemudian hari 
(Syamsuddin, 2009). Piutang merupakan salah satu bentuk investasi yang menyerap sebagian besar modal kerja perusahaan, terutama pada perusahaan manufaktur. Peningkatan piutang yang merupakan dampak dari meningkatnya piutang tak tertagih merupakan hal yang perlu menjadi perhatian lebih oleh manajemen. Untuk itu sebelum perusahaan mengambil keputusan untuk menjual produknya secara kredit, maka perlu diperhitungkan terlebih dahulu berapa dana atau modal kerja yang akan mengendap di piutang dan bagaimana mekanisme pembayarannya sehingga risiko kerugian piutang (piutang tak tertagih) dan biaya-biaya yang akan timbul jika ada piutang tak tertagih bisa diatasi. Piutang timbul karena perusahaan melakukan penjulan secara kredit untuk meningkatkan volume usahanya.

Menurut Keown (2010), modal kerja yang minimal dapat diperoleh dengan cara mempercepat penagihan piutang. Percepatan penagihan piutang maka akan dapat mempercepat Siklus Konversi Kas, sehingga modal kerja perusahaan lebih efisien. Perusahaan juga akan memiliki oppotunity cost, karena adanya waktu untuk merubah piutang menjadi kas, dimana kas tersebut dapat diinvestasikan pada deposito atau investasi lainnya, sehingga dapat meningkatkan profitabilitas perusahaan.

Hasil dari penelitian menunjukan bahwa Days of Sales Outstanding memiliki pengaruh positif tidak signifikan terhadap Return on Asset. Rata-rata waktu penagihan piutang usaha adalah selama 84 hari atau hampir selama 3 bulan, bahkan pada sampel ditemukan Days of Sales Outstanding tertinggi selama periode pengamatan adalah selama 271 hari atau 9 bulan. Hal ini menunjukan bahwa dibutuhkan waktu minimal 3 bulan oleh perusahaan pupuk negara untuk mengkonversikan piutangnya menjadi kas, sedangkan waktu yang dibutuhkan untuk mengkonversi piutang menjadi kas rata-rata industri kimia adalah 64 hari (Syarif dan Wilujeng, 2009). Hasil ini mencerminkan bahwa tingkat kolektibilitas piutang perusahaan masih di bawah rata-rata industri kimia. Hasil penelitian ini tidak signifikan karena lamanya penagihan piutang tersebut merupakan hal yang tidak bisa dikendalikan oleh perusahaan pupuk negara mengingat 59,69\% dari total piutang usaha perusahaan pupuk negara merupakan piutang subsidi oleh pemerintah. Plafon pembayaran subsidi per tahun disesuaikan dengan anggaran subsidi pupuk yang disetujui dalam APBN.

Kecepatan waktu verifikasi penyaluran pupuk subsidi kepada petani yang digunakan sebagai dasar oleh perusahaan pupuk negara untuk menagih subsidi pupuk kepada pemerintah, tidak memiliki pengaruh yang signifikan untuk mempercepat Days of Sales Outstanding, karena pembayaran subsidi oleh pemerintah terbatas oleh anggaran yang sudah disetujui dalam APBN. Fenomena ini berdampak pada tingginya saldo hutang subsidi oleh pemerintah kepada produsen pupuk negara per 31 Desember 2016 sesuai Laporan Keuangan Pemerintah Pusat Tahun 2016 (audited) sebesar Rp 12,107 triliyun, disisi lain total piutang subsidi per 31 Desember 2016 dari kelima produsen pupuk negara sebesar Rp 19,487 triliyun, sehingga ada selisih sebesar Rp 7,380 triliyun yang masih akan akan dianggarkan oleh pemerintah di tahun selanjutnya. Selisih piutang tersebut juga masih belum tentu disetujui semua dalam APBN tahun berikutnya, sehingga dapat diprediksi Days of Sales Outstanding pada tahun-tahun selanjutnya masih belum dapat dipercepat oleh perusahaan pupuk negara. Hasil ini berbanding terbalik dengan hasil penelitian Deloof (2013), Tu dan Nguyen (2012), Karaduman, et al (2010), Attari dan Raza (2012) dan Akoto, et al (2013).

\section{Pengaruh Days of Sales in Inventory terhadap Return on Asset}

Days of Sales in Inventory menurut Gitman (2009) adalah rata-rata jumlah hari penjualan dalam persediaan. Rasio ini mengindikasikan berapa lama waktu yang dibutuhkan oleh perusahaan untuk merubah persediaan bahan baku, barang dalam proses 
Kurniawan, Pengaruh Manajemen Modal Kerja

dan produk jadi menjadi penjualan. Tingkat Days of Sales in Inventory yang singkat mengindikasikan perputaran persediaan yang cukup cepat dan berdampak pada kinerja perusahaan yang bagus, begitu pula sebaliknya jika tingkat Days of Sales in Inventory tinggi mengindikasikan bahwa investasi perusahaan cukup berisiko karena tingkat persediaan tergantung pada tingkat penjualan. Persediaan merupakan komponen dari harta lancar yang mungkin menerima perhatian yang lebih di perusahaan manufaktur karena memiliki pengaruh langsung terhadap laba perusahaan dan pada umumnya persediaan merupakan aset terbesar kedua setelah harta tetap serta karena perusahaan fokus kepada operasional pabrik yang efisien. Tujuan pengelolaan persediaan adalah mendapatkan total biaya persediaan yang diperlukan menjadi rendah (efisien) guna mendukung operasional perusahaan.

Pengelolaan persediaan merupakan suatu kegiatan yang sulit, dimana kesalahan dalam menentukan tingkat persediaan dapat berakibat fatal pada pengelolaan modal kerja mereka. Dalam mengelola persediaan, muncul biaya-biaya yang harus ditanggung perusahaan (Brealey, 2008). Berdasarkan hal tersebut maka periode persediaan harus dipercepat agar dapat menekan biaya-biaya tersebut sehingga hal ini akan dapat menguntungkan bagi perusahaan. Di sisi lain perusahaan harus menjaga agar tidak terjadi kehabisan persediaan yang berakibat perusahaan tidak dapat memenuhi permintaan pelanggan (Syamsuddin, 2009).

Upaya mempercepat periode persediaan dapat meningkatkan keuntungan perusahaan dikarenakan pengelolaan persediaan ini menimbulkan biaya-biaya yang harus ditanggung perusahaan. Dengan mempercepat periode ini maka dapat mengurangi biayabiaya yang harus ditanggung perusahaan, sehingga hal ini dapat meningatkan profitabilitas perusahaan, akan tetapi harus diwaspadai agar tidak terjadi kehabisan persediaan yang berakibat perusahaan tidak dapat memenuhi permintaan pelanggan. Untuk mencapai tingkat perputaran persediaan yang efisien diperlukan perencanaan dan pengawasan persediaan yang efisien (Djarwanto,2001).

Besar persediaaan umumnya dipengaruhi oleh harapan-harapan akan volume penjualan dan tingkat harga di masa datang. Harapan dapat menjual lebih banyak atau harga jual akan meningkat, mendorong perusahaan untuk memperbanyak persediaan barang (Djarwanto, 2001). Perputaran persediaan yang semakin meningkat menunjukkan tingkat perputaran dana yang tertanam pada persediaan juga tinggi. Perputaran persediaan yang lambat menunjukkan lamanya persediaan tersimpan di perusahaan, sehingga hal ini dapat memperbesar biaya persediaan, dan akan mempengaruhi laba perusahaan (Fitri, 2013). Hal ini dikarenakan apabila jumlah persediaan terlalu tinggi, dana yang tertanam dalam persediaan juga akan tinggi, sehingga akan menimbulkan kerugian.

Menurut Brigham (2011), kelebihan persediaan akibat tingkat perputaran persediaan yang lambat, tentunya tidak produktif dan mencerminkan investasi dengan tingkat pengembalian atas aset (ROA) rendah atau nol. Disisi lain menurut Ang (2007) menyatakan bahwa semakin besar inventory turnover akan semakin baik karena mencerminkan penggunaan seluruh aset yang semakin efisien yang digunakan untuk menunjang kegiatan penjualan.

Rata-rata hari yang diperlukan perusahaan pupuk negara untuk mengkonversi persediaannya menjadi penjualan adalah 74 hari atau 2,5 bulan, sedangkan rata-rata Days of Sales in Inventory untuk perusahaan kimia adalah 55 hari (Syarif dan Wilujeng, 2009). Tingginya rata-rata hari yang diperlukan perusahaan pupuk negara untuk mengkonversi persediaannya menjadi penjualan dibandingkan dengan rata-rata industri perusahaan kimia (Syarif dan Wilujeng, 2009), karena perusahaan pupuk perlu perencanaan stock bahan baku yang baik mengingat $80 \%$ bahan baku masih berasal dari impor. Perubahan musim tanam juga berpengaruh pada persediaan barang jadi, pada musim tanam persediaan barang jadi relatif sedikit demikian sebaliknya ketika memasuk musim panen, 
maka stock persediaan barang jadi relatif tinggi. Hasil penelitian menunjukan bahwa Days of Sales in Inventory memiliki pengaruh negatif signifikan terhadap Return on Asset. Hasil penelitian ini mengindikasikan bahwa mempercepat Days of Sales in Inventory akan menghemat biaya penyimpanan bahan baku, work in process dan meminimalisir kerusakan barang jadi, sehingga dapat meningkatkan profitabilitas perusahaan pupuk negara. Dilihat dari data time series, Days of Sales in Inventory perusahaan pupuk negara mengalami penurunan yang cukup signifikan untuk periode tahun 2016-2020, kecuali untuk PT Pupuk Iskandar Muda yang cenderung mengalami kenaikan tiap tahunnya dampak dari meningkatnya nilai persediaan barang jadi urea dan ammonia akibat kalah bersaing di penjualan retail non subsidi disektor perkebunan dan rendahnya permintaan ammonia oleh industri vetsin.

Rata-rata Days of Sales in Inventory perusahaan pupuk negara adalah selama 73,84 hari. Penurunan Days of Sales in Inventory perusahaan pupuk negara merupakan hasil dari perencanaan dan pengawasan persediaan yang efisien yang menyesuaikan tingkat produksi dan pergantian musim. Seperti diketahui sebelumnya bahwa $80 \%$ bahan baku yang dibutuhkan untuk proses produksi oleh perusahaan pupuk negara masih impor, tentu dengan perencanaan dan pengawasan yang baik akan menghemat biaya pengiriman dan bahan penyimpanan bahan baku, sehingga berdampak pada cost reduction dan meningkatkan profitabilitas perusahaan. Perusahaan pupuk negara mempunyai staf pengendalian operasi yang memiliki fungsi untuk merencanakan pembelian bahan baku, kuantum produksi dan rencana penjualan, sehingga jumlah persediaan yang optimal dapat ditentukan. Penentuan persediaan yang optimal sangat diperlukan pada perusahaan pupuk negara, mengingat tingginya penjualan pupuk pada saat musim tanam/hujan, dan mengalami penurunan pada saat musim panen/kemarau. Di sisi lain harga bahan baku pupuk juga fluktuatif dan bergantung pada nilai tukar rupiah terhadap USD mengingat perusahaan pupuk masih impor dalam pengadaan bahan bakunya, tentu hal ini perlu perencanaan untuk membeli pada saat harga turun tetapi tetap dengan mempertimbangkan kebutuhan produksi dan volume penjualannya, sehingga dapat menghemat biaya penyimpanan.

Hasil penelitian ini sesuai dengan penelitian yang dilakukan oleh Deloof (2013), Tu dan Nguyen (2012), Karaduman, et al (2010), Attari dan Raza (2012) akan tetapi berbanding terbalik dengan temuan Ullah, et al (2007). Dari penelitian ini dapat disimpulkan dengan mempercepat Days of Sales in Inventory, maka Return On Equity perusahaan pupuk negara akan meningkat.

\section{Pengaruh Days of Payables terhadap Return on Asset}

Pemenuhan kewajiban lancar perusahaan sangatlah penting dalam manajemen modal kerja, sebab ada beberapa kewajiban lancar yang harus dipenuhi tepat waktu tanpa mempedulikan kondisi keuangan perusahaan. Manajemen harus memilah kewajiban lancara mana saja yang harus dipenuhi terlebih dahulu. Salah satu kewajiban lancar yang harus dipenuhi terlebih dahulu atau diprioritaskan adalah pembayaran kepada suplier. Pembayaran kepada suplier dapat dianalisa dengan menggunakan periode pembayaran rata-rata. Periode pembayaran rata-rata mencerminkan jumlah hari yang dibutuhkan perusahaan untuk memenuhi tagihan kewajiban jangka pendeknya dan atau jangka panjang yang jatuh tempo (Subramarnyam dan Wild, 2010) Days of Payable in Outstanding menurut Brigham dan Ehrhardt (2005) adalah rata-rata lama waktu antara pembelian bahan dan tenaga kerja Dengan pembayarannya. Salah satu upaya untuk mempersingkat siklus kas adalah dengan menunda jangka waktu pembayaran yang seharusnya menjadi kewajiban perusahaan, dengan begitu perusahaan mempunyai 
kesempatan menggunakan dana yang seharusnya untuk memenuhi kewajibannya untuk dapat diinvestasikan kembali.

Menurut Munawir (2007), utang dagang mempunyai hubungan yang erat dengan pembelian barang dagangan atau bahan baku karena perusahaan yang besar pada umumnya pembeliannya dilakukan secara kredit. Semakin tinggi perputaran utang dagang, semakin cepat perusahaan di dalam membayar utang. Utang usaha pada dasarnya menguntungkan bagi perusahaan karena dapat menggunakan bahan baku tanpa harus membayar terlebih dahulu. (Brealey et al., 2008), jika pembayarannya diperlambat maka hal ini semakin menguntungkan perusahaan. Di sisi lain perusahaan harus tetap menjaga relasi yang baik dengan pemasok dan tetap memanfaatkan potongan tunai yang menguntungkan perusahaan (Syamsuddin, 2009). Apabila perusahaan membayar mampu menunda pembayaran hutang-hutangnya tanpa meningkatkan biaya operasi maka profitabilitas perusahaan akan semakin tinggi (Brigham dan Houston 2011).

Hasil penelitian menunjukan bahwa Days of Payables memiliki pengaruh negatif signifikan terhadap Return on Asset. Hasil penelitian ini mengindikasikan bahwa dengan mempercepat pembayaran kewajiban jangka pendek, maka perusahaan pupuk negara akan dapat meningkatkan Return on Asset-nya. Rata-rata Days of Payables selama periode pengamatan adalah 189,16 hari atau setara 6,3 bulan sedangkan rata-rata Days of Payables untuk industri kimia adalah 36 hari. Tingginya Days of Payables perusahaan pupuk negara dibandingkan dengan rata-rata industri kimia (Syarif dan Wilujeng, 2009), karena keterbatasan modal kerja perusahaan pupuk negara. Modal kerja perusahaan pupuk negara banyak tertanam di piutang usaha, sehingga untuk pemenuhan hutang lancar memerlukan dana pinjaman dari pihak ketiga atau perbankan. Penerimaan piutang usaha yang membutuhkan waktu yang relatif lama, merupakan faktor yang uncontrolable karena tergantung alokasi anggaran subsidi pada APBN. Hal ini berdampak pada penarikan pinjaman yang cukup besar yang mengakibatkan meningkatnya bunga pinjaman, sehingga berdampak pada turunnya profitabilitas perusahaan.

Perusahaan apabila mampu menunda pembayaran hutang jangka pendek tanpa meningkatkan biaya operasi maka profitabilitas perusahaan akan semakin tinggi. Jika skenario ini diimplikasikan pada perusahaan pupuk negara, maka risiko peningkatan biaya operasi akan meningkat, mengingat seperti diketahui sebelumnya bahwa $80 \%$ bahan baku yang dibutuhkan oleh perusahaan pupuk negara masih impor, tentu dengan menunda pembayaran pengadaan bahan baku kepada suplier berakibat menurunnya profitabilitas perusahaan. Penundaan pembayaran kepada suplier berakibat meningkatnya risiko rugi selisih kurs, karena fluktuatifnya dan cenderung melemahnya nilai tukar IDR terhadap USD. Peran manager keuangan sangat dibutuhkan dalam menjaga arus kas dan mengetahui waktu yang tepat untuk membayar kewajiban pendeknya, sehingga berdampak pada semakin pendeknya siklus konversi kas dan dapat meningkatkan profitabilitas perusahaan karena adanya efisiensi biaya operasional.

Hasil penelitian ini sesuai dengan penelitian yang dilakukan oleh Karaduman, et al (2010), akan tetapi berbanding terbalik dengan hasil penelitian Ullah, et al (2007). Dari penelitian ini dapat disimpulkan bahwa dengan mempercepat pembayaran kewajiban jangka pendek, maka perusahaan pupuk negara akan dapat meningkatkan Return on Asset-nya.

\section{SIMPULAN DAN REKOMENDASI}

Days of Sales in Inventory memiliki pengaruh signifikan terhadap proftabilitas perusahaan pupuk negara, ketika perusahaan negara mampu mengkoversi persediaannya menjadi penjualan dengan cepat, maka peluang untuk meningkatkan Return on Asset-nya juga sangat besar. 
Days of Payables memiliki pengaruh signifikan terhadap profitabilitas perusahaan pupuk, ketika perusahaan pupuk negara mempercepat pembayaran kewajiban jangka pendek, maka risiko kerugian selisih kurs dapat diminimalisir sehingga berdampak pada peningkatkan Return On Aset perusahaan pupuk negara.

Selama periode pengamatan aset perusahaan pupuk negara mengalami kenaikan yang cukup signifikan. Aset terebut didominasi oleh piutang dan persediaan, serta dapat dikatakan bahwa kualitasnya kurang baik, sehingga dapat kenaikan aset harus diikuti kualitas aset untuk meningkatkan profitabilitas perusahaan.

Perusahaan pupuk negara diharapkan dapat mempercepat Days of Sales in Inventory untuk menghemat biaya penyimpanan bahan baku akan tetapi dengan mempertimbangkan ketersediaan stock bahan baku mengingat $80 \%$ bahan baku masih impor serta mempertimbangan kebutuhan produksi sesuai permintaan pasar.

Perusahaan pupuk negara diharapkan dapat mempercepat pelunasan ke pemasok setelah piutang subsidi dari pemerintah terbayarakan sehingga dapat mengurangi penarikan pinjaman dari pihak ketiga yang digunakan untuk menalangi pembayaran kewajiban jangka pendek, sehingga berdampak penuruanan bunga serta meningkatkan profitabilitas perusahaan. Perusahaan pupuk negara perlu melakukan melakukan kontrak forward untuk pengadaan bahan baku guna meminimalisir risiko rugi selisih kurs mengingat bahwa $80 \%$ bahan baku yang dibutuhkan oleh perusahaan pupuk negara masih import.

Peningkatan total aset perusahaan pupuk negara sebaiknya juga diimbangi dengan kualitas aset yang produktif dengan meminimalisir jumlah piutang subsidi melalui pembentukan tim task force piutang subisidi yang bertugas memantau verifikasi penjaualan pupuk subsidi dan mengusulkan ke kementerian pertanian besaran subsidi pupuk yang diajukan pada APBN.

\section{DAFTAR PUSTAKA}

Akoto, et al. 2013. Working capital management and profitability: Evidence from Ghanaian listed manufacturing firms. Journal of Economic and International Finance Vol. 5. 373-379

Ang, Robert, 2007, Buku Pintar Pasar Modal Indonesia (The Intelligent Guide To Indonesian Capital Market). Edisi Pertama, Mediasoft Indonesia, Jakarta.

Anonimous, 2016, Persaingan Pupuk Ketat (online) (http:// www. kompas.com. Diakses tanggal 10 Juli 2021)

2016. Indonesia GDP (online) (http:// www.tradingekonomi.com. Diakses tanggal 10 Juli 2021)

Ardyan Mohammad, 2014, Mentan dan Menko Beda Pendapat Soal Pencabutan Pupuk Subsidi (http:// www.merdeka.com. Diakses tanggal 10 Juli 2021).

Attari and Raza. 2012. The Optimal Relationship of Cash Conversion Cycle with Firm Size and Profitability. International Journal of Academic Research in Business and Social Sciences Vol. 2 No 4, 189-203

Aviliani, 2008, Peran BRI dalam Membangun Ekonomi Berbasis Agribisnis yang Tangguh dan Kompetitif, Agrimedia, Volume 13. 
Bambang Riyanto, 2011. Dasar-Dasar Pembelanjaan Perusahaan. Edisi Keempat. Penerbit : BPFE, Yogyakarta.

Baroto,Teguh. 2002. Perencanaan dan Pengendalian Produksi. Cetakan Pertama, Jakarta: Ghalia Indonesia.

Bilal, et al. 2013, Influencing Bank Specific and Macroeconomic Factors on Profitability of Commercial Banks: A Case Study of Pakistan, Research Journal of Finance and Accounting, Vol 4, No 2

Braun, M. and B. Larrain. 2005. Finance and The Business Cycle: International, Inter Industry Evidence. Journal of Finance 60 (3),1097-1128.

Brealey, et al. 2008. Dasar-Dasar Manajemen Keuangan Perusahaan, Jilid I, Erlangga, Jakarta.

Brigham, and Ehrhardt. 2005. Financial Management: Theory and Practice, Eleventh Edition, Thomson South Western Ohio, United States of America.

Brigham, Eugene F. and Houston, 2011. Manajemen Keuangan, Edisi 8 Erlangga, Jakarta.

Brigham, Eugene F. and Gapenski, Louis C. 2006, Financial Management: Theory and Practice, 9th edition, Florida: Harcourt College Publisher.

Burhan Bungin, 2009, Metodologi Penelitian Kuantitatif, Edisi Pertama, Cetakan Keempat, Kencana Prenada Media Group, Jakarta

Caballero, J., Teruel, G., and Solano, P. (2009), Working capital management in SMEs, Accounting and Finance, Vol 50 No 3, pp. 511-527.

Deloof, M, 2003. Does Working Capital Management Affect Profitability of Belgian Firm? Journal of Business Finance \& Accounting, 30(3-4), 573-588.

Djarwanto. 2001. Pokok - Pokok Analisa Laporan Keuangan, Edisi Pertama. Cetakan Kedelapan, BPFE, Yogyakarta.

Einarsson, T., and M. H. Marquis. (2001). Bank intermediation over the business Cycle. Journal of Money, Credit and Banking 33 (4), 876-899.

Eljelly, A. 2004. Liquidity -profitability Tradeoff: An empirical investigation in an Emerging Market, International Journal of Commerce \& Management, Vol 14 No 2 Hal 48-61

Enqvist J., M Graham and J. Nikkinen. 2012. The Impact of Working Capital Management on Firm Profitability in Different Business Cycles: Evidence from Finland. Working Paper

Esra , Martha Ayerza dan Prima Apriweni . 2002 . Manajemen modal kerja. Jurnal ekonomi Perusahaan .STIE iBii. Jakarta. 
Fitri Meria. 2013, Pengaruh Perputaran Piutang Usaha dan Perputaran Persediaan Terhadap Tingkat Profitabilitas Perusahaan Otomotif dan Komponen yang Terdaftar di Bursa Efek Indonesia. Jurnal Pendidikan Ekonomi.

Gitman, and Lawrence. 2009. Principles of Managerial Finance. Pearson Addison Wesley, United States

Gujarati, 2005. SPSS versi 16 Mengolah Data Statistik Secara Profesional. Gramedia Pustaka Utama, Jakarta.

Husnan, Suad dan Enny Pudjiastuti. 2006. Dasar-Dasar Manajemen Keuangan. Edisi Kelima. UPP STIM YKPN. Yogyakarta.

I Made Sudana, 2011, Manajemen Keuangan Perusahaan, Erlangga, Jakarta.

Imam Ghozali, 2006, Aplikasi Analisis Multivarate dengan Program SPSS, Badan Penerbit Universitas Diponegoro, Semarang.

James C. Van Horne., \& John M. Wachowicz jr. 2012. Prinsip-Prinsip Manajemen Keuangan (Edisi 13, Buku 1). Jakarta: Salemba Empat.

Jogiyanto, Hartono. 2010, Teori Portofolio dan Analisis Investasi. Edisi Ketujuh, Yogyakarta : BPFE

Karaduman H, et al. 2010. Effects of Working Capital Management on Profitability: the Case for Selected Companies in the Istanbul stock exchange (2005-2008). International Journal Of Economics And Finance Studies Vol 2, No 2, 47-54

Kasmir. 2011. Analisis Laporan Keuangan. Rajawali Pers :Jakarta

Kementerian Keuangan. 2015. Laporan Keuangan Pemerintah Pusat Tahun 2014 (Audited), Jakarta hal 149-151.

Keown, et al. 2010. Manajemen Keuangan: Prinsip-Prinsip dan Aplikasi. Edisi 9, Indeks. Jakarta.

Korajczyk RA, and Levy A. 2003. Capital Structure Choice: Macroeconomic Conditions and Financial Constraints. Journal of Financial Economics 68(1), 75-109.

Martani, Dwi dan Ronald R Munaiseche. 2009. Factors Affecting Profitability of Multi Finance Company in Indonesia, Jurnal publikasi Universitas Indonesia.

Martono dan Agus Harjito. 2008. Manajemen Keuangan. Ekonisia : Yogyakarta

Manoori dan Muhammad. 2012. Determinants of Working Capital Management: Case of Singapore Firms. Research Journal of Finance and Accounting ISSN 2222-1697 (Paper)

McEachern, William A.2000. Ekonomi Makro. Penerbit Salemba Empat. Jakarta. 
Munawir, S, 2007. Analisa Laporan Keuangan. Edisi keempat, cetakan keempat belas. Yogyakarta:Liberty.

Muscettola, M. 2014. Cash Conversion Cycle and Firm's Profitability: An Empirical Analysis on a Sample of 4,226 Manufacturing SMEs of Italy. International Journal of Business and Management; Vol. 9, No. 5; 25-35

Napompech, K. 2012. Effects of Working Capital Management on the Profitability of Thai Listed Firms. International Journal of Trade, Economics and Finance, Vol. 3, No. 3.,227-232

Nisa Fidyati, 2003. Faktor-Faktor yang Mempengaruhi Jebijakan Hutang Perusahaan. Jurnal Ekonomi Manajemen dan Akuntansi Vol. 1 No. 1 Januari,17-34.

Niskanen, J., and Niskanen, M., 2006. The Determinants of Corporate Trade Credit Polices in a Bank-DominatedFinancial Environment: The Case of Finnish Small Firms. European Financial Management, 12 (1), 81-102.

Nur Indriantoro., dan Bambang Supomo. 2002, Metodologi Penelitian Bisnis Untuk Akuntansi dan Manajemen, Penerbit BPFE, Yogyakarta

Quayyum, S. 2011. Effects of Working Capital Management and Liquidity: Evidence from the Cement Industry of Bangladesh. Journal of Business and Technology Volume VI Number 01, 37-41

Sawir, A, 2008. Analisis Kinerja Keuangan dan Perencanaan Keuangan Perusahaan. Cetakan Ketiga. PT. Gramedia Pustaka Umum, Jakarta

Sekaran, Uma 2003, Metodologi Penelitian Bisnis, Terjemahan oleh Kwan Men

Yon, 2007, Edisi Keempat, Buku Satu, Salemba Empat, Jakarta

Singgih Santoso, 2001, Buku Latihan SPSS Statistik Parametrik, Edisi Kedua, PT Elex Media Komputindo, Jakarta

Soemarso S.R, 2009, Akuntansi : Suatu Pengantar. Buku Satu Edisi Lima, Jakarta: Salemba Empat

Srairi., and Samir Abderrazek. 2009. Factors Influencing the Profitability of Conventional and Islamic Commercial Banks in GCC Countries, Review of Islamic Economic, Vol.13, No.1,2009, 5-30.

Subramanyam R. and Wild Jhon, 2010, Analisis Laporan Keuangan, Salemba Empat, Jakarta.

Sugiyono. 2013. Metode Penelitian Bisnis. Cetakan ketiga. Alfabeta, Bandung

Sukartha, Made, 2007, Pengaruh Manajemen Laba, Kepemilikan Manajerial, dan Ukuran Perusahaan pada Kesejahteraan Pemegang Saham Perusahaan Target Akuisisi. Jurnal Riset Akuntansi. 
Suharyadi., dan Purwanto S.K. 2009, Statistik Ekonomi dan Keuangan Modern, Buku Dua, Salemba Empat, Jakarta

Supardi, 2005, Metodologi Penelitian Ekonomi dan Bisnis, Cetakan Pertama, UII Press, Yogyakarta

Suryaputri, Rossje V dan Christina Dwi Astuti, 2003, Pengaruh Faktor Leverage, Dividend Payout, Size, Earnings Per Share and Country Risk terhadap Price to Book Value, Media Riset Akuntansi, Auditing dan Informasi, Vol. 3, No. 1 April, hal. 123.

Syamsuddin, 2009, Manajemen Keuangan Perusahaan, PT. Raja Grafindo Persada, Jakarta

Syarif dan Wilujeng. 2009 . Cash Conversion Cycle dan Hubungannya dengan Ukuran Perusahaan, Profitabilitas dan Manajemen Modal Kerja. Jurnal Ekonomi dan Bisnis, Nomer 1 hal 61-69

Tandelilin, Eduardus. 2001. Analisis Investasi dan Manajemen Portofolio, Edisi Pertama, BPFE, Yogyakarta.

Tu., and Nguyen. 2012. Relationship Between Working Capital Management and Profitability - Empirical evidence from Vietnamese Listed firms.

Ullah, et al, 2007. Working Capital Management and Profitability An Analysis of Firms of Textile Industry of Pakistan. Journal of Managerial SciencesVolume VI Number 2, 155-165. 